\title{
Examining the Impact of Dubai Smart Government Characteristics on User Satisfaction
}

\author{
Obeid Alshamsi, Ali Ameen, Osama Isaac, Gamal S. A. Khalifa, Amiya Bhumic
}

\begin{abstract}
Information and telecommunication technology (ICT) are today practiced in various public sectors and are considered as a cost-effective and convenient means to encourage openness, transparency, and to reduce corruption. It has also put innovation and ICT more than ever at the heart of smart development. Presently, this phenomenon has also been adopted by governments so as to cope with various problems created by increasing urban populations in their countries. The main objective of this study is to examine the influence of Dubai smart government characteristics on the user satisfaction. Online survey was used to collect data for this study, the sample size was determined as 250 users of Dubai smart government services, who are users who got the services from five major strategic or government partners of smart government establishment: Dubai Police, RTA, DEWA, DHA, and Dubai Municipality. PLS (Partial Least Squares) SEM-VB (Structural Equation Modelling-Variance Based) was employed to assess the research model by utilising the software SmartPLS 3.0. This paper adds to the existing literature of smart government characteristics (Information System Quality, Relationship with Public Agencies, Leadership, Accountability and Transparency, and Productivity) and user satisfaction (Usefulness, Awareness, Service Quality, Trust, and Social Influence). The results of this study have the potential to give further insights into Dubai government to improve their users' satisfaction.
\end{abstract}

Keywords: Dubai smart government; user satisfaction; Dubai; $U A E$.

\section{INTRODUCTION}

Information and telecommunication technology (ICT)s are today practiced in various public sectors and are considered as a cost-effective and convenient means to encourage openness, transparency, and to reduce corruption [1]. Moreover, it has created a new playing field for worldwide competition with an increasing premium for knowledge, learning, agility, and connectedness. It has made it possible to capture and deploy information and knowledge for all kinds of activity. It has also put innovation and ICT more than ever at the heart of smart development. Presently, this phenomenon has also been adopted by governments so as to cope with various problems created by increasing urban populations in their countries [2, 3].

One of the key goals of public management

Revised Manuscript Received on September 25, 2019

Obeid Alshamsi, Lincoln University College, Selangor, Malaysia

Ali Ameen, Lincoln University College, Selangor, Malaysia

Mohammed Nusari, Lincoln University College, Selangor, Malaysia

Gamal S. A. Khalifa, Lincoln University College, Selangor, Malaysia

Amiya Bhumic, Lincoln University College, Selangor, Malaysia or provision of government services is to improve citizen satisfaction with the government, particularly public service performance, efficiency, effectiveness, and responsiveness, among other performance dimensions. In addition, the growing information needs by different stakeholders, increasing urban population to a greater extent, the lack of effective and efficient communication channels between the government and residents, a lack of best knowledge management practices are a few critical issues that the UAE government is aiming to resolve through smart government initiatives in the country. Moreover, it is clear that the ultimate outcome of Dubai smart government initiatives is to enhance the quality of lives in the city, as well as happiness, leading to increased residents' satisfaction in Dubai towards the government or public services. Since the Dubai government has been developing, promoting and executing various smart government initiatives since May 2013, there is no empirical study or investigation whether they have effectively been adopted by the residents and affect the residents' satisfaction level.

In the view of Dubai Smart government establishment, it can be noted that public management is carried out through its strategic partners such as Dubai Electricity and Water Authority (DEWA); The Executive Council; Dubai Health Authority (DHA); Roads \& Transport Authority (RTA); Dubai Tourism; Dubai Police; Dubai Municipality Department of Economic Development (DED) etc. Hence, it is clear that those government departments may directly or indirectly be able to influence the residents' satisfaction. Therefore, the importance of studying the significant association between residents' satisfaction and Dubai smart government establishment.

\section{Literature REVIEW}

\section{A. Dubai Smart Government Characteristics (DSG)}

Smart governance is defined as a subset of the smart city domain where an open dialogue between citizens and city officials is enabled through an information and communications technology (ICT) platform 
[4]. Smart governance includes "the aspects of political participation, services for citizens as well as the functioning of the administration" [5]. By reviewing all of above definitions, this paper defines smart government as the promotion of smart city initiatives to serve its beneficiaries and public administration/management.

In order to derive the critical factors influencing smart government performance, several journal articles, as well as the researcher's opinions could be used. According to literature review, it is found that there are several studies that investigated the success or failure factors of e-government and smart government [6-12]. Accordingly, following factors can be established as the critical factors affecting Dubai smart government performance $[8,12-15]$.

The integration of ICT with development projects can change the urban landscape of a city and offer a number of potential opportunities, they can enhance the management and functioning of a city [16]. According to Elkadi (2013) [11], information system factors directly impact the success or failure of e-government. As highlighted by DeLone \& McLean (2013) [10], information system success factors encompasses several aspects including the quality of information, system, and services.

Furthermore, though smart government initiatives are implemented in various governmental departments, such initiatives will not be successful as long as there is no strong relationship between governmental departments and people or beneficiaries. According to Al-Shafi \& Weerakkody (2010) [6], a poor trust relationship between people and public agencies has led to the failure of some smart government initiatives in Qatar, a neighboring state of the UAE. Hence, it can be conceptualized that the government's strong trust relationship between people and public agencies or governmental departments positively affect smart government performance.

Moreover, Leadership and management is the most crucial dimension affecting the successfulness of smart government initiatives. As part of the leadership's mandate, SDG is entrusted with many tasks and powers including: proposing the general strategy of the smart government; overseeing smart transformation processes at the level of government entities; reviewing government entities' plans and budgets related to smart transformation, IT, smart services and infrastructure; and proposing the legislation necessary for easing the smart transformation process [17]. Hence, it can be argued the degree to which those activities are led and manage will be determinants of Smart Dubai Government Establishment.

Additionally, in governance, accountability is referred to answerability, blameworthiness, liability, and the expectation of account-giving, according to Dykstra (1939) [18]. Empirical studies indicate that the governance model of Smart Cities initiatives follow the same principles of the governance model preconized by e-government research area [7, 19, 20] that is, being transparent and accountable.

Finally, economic development can be concerned as the critical external factor affecting the success of smart government initiatives. Economy is the major driver of smart city initiatives, and a city with a high degree of economic competitiveness is thought to have one of properties of a smart city, and thereby smart government [9]. Smart City Indicator survey in 2017 conducted by Johnson Controls amongst 150 smart city leaders found that economic development was one of the critical drivers of smart city initiatives [21]. Hence, it can be assumed that there is a direct association between successfulness of smart government and Dubai's economy performance. Consequently, the following hypotheses are proposed:

H1: Dubai smart government characteristics has a positive effect on Users' satisfaction.

\section{B. User Satisfaction (SAT)}

In the context of this study, beneficiaries' satisfaction is defined as noted in the study of Chatfield \& Alanazi (2013) [22] who defined it as a pleasurable or positive emotional state resulting from the appraisal of using transactional e-government self-services delivery options to achieve the citizen's personal task such as seeking conference travel, and reimbursement from government. However, it should be noted that such definition has been linked with e-government and smart government $[13,15]$.

By considering different models of user satisfaction such as technology acceptance model Davis (1989) [23], end users' adoption model [24], and trust and risk model [25], following factors have been integrated into the variable of beneficiaries' satisfaction included in the current study's model.

Perceived usefulness is one of the strongest signs of technology adoption as it reflects a significant effect across many technologies and applications, according to Thunibat, Azan Mat Zain, \& Ashaari (2011) [26]. Also, the relevant studies have found out that perceived usefulness has a significant effect on the intention to use or the adoption of m-government or e-government services [24, 27]. Accordingly, it is arguably clear that perceived usefulness have a positive impact on beneficiaries' intention to use smart government platforms and thereby on their satisfaction level.

Moreover, awareness is knowledge of people as to technology and the 
availability of electronic services [28]. Abdelghaffar \& Magdy (2012) [29] implies that awareness is the first step towards users knowing that the government provides its services over the Internet technology. The lack of awareness has a negative impact on citizens' intentions to adopt e-government and m-government services [24]. In view of that, it can arguably said that the lack of awareness leads to a decline in interest in smart government services, and thereby users' satisfaction.

Furthermore, the quality of information, system, and services provided by smart government initiatives are said to be having a remarkable impact on end users' intention to use and their satisfaction [30]. This is clearly evident from information system success model developed by a study [10].

In addition, trust and public safety can be concerned as a crucial determinant of the satisfaction of beneficiaries of smart government services. Smart City Indicator survey conducted by Johnson Controls, point out the trust and public safety as one of the important drivers of smart city initiatives all over the world. A model of trust and risk in e-government adoption, which was proposed by [25] can be used to review the above claim.

Finally, according to Almuraqab \& M. Jasimuddin (2017) [24], social influence is the degree to which an individual perceives important that other people such as family and friends believe he or she should use the new system. It is vital to realize the importance of the influence of friends and family on decisions to use a technology. Social influence is emerging as a factor in the intention to use smart government services as the communities are increasingly used advanced ICTs in their daily activities. Hence, such factors can be categorized as another dimension influencing the level of user's satisfaction over smart government services [27].

\section{RESEARCH METHOD}

\section{A.Overview of the Proposed Conceptual Framework}

In figure1, conceptual model to theoretically represent how Dubai smart government can influence the users' satisfaction. The model is developed and operationalized by reviewing the possible determinants of Dubai smart government characteristics and users' satisfaction.

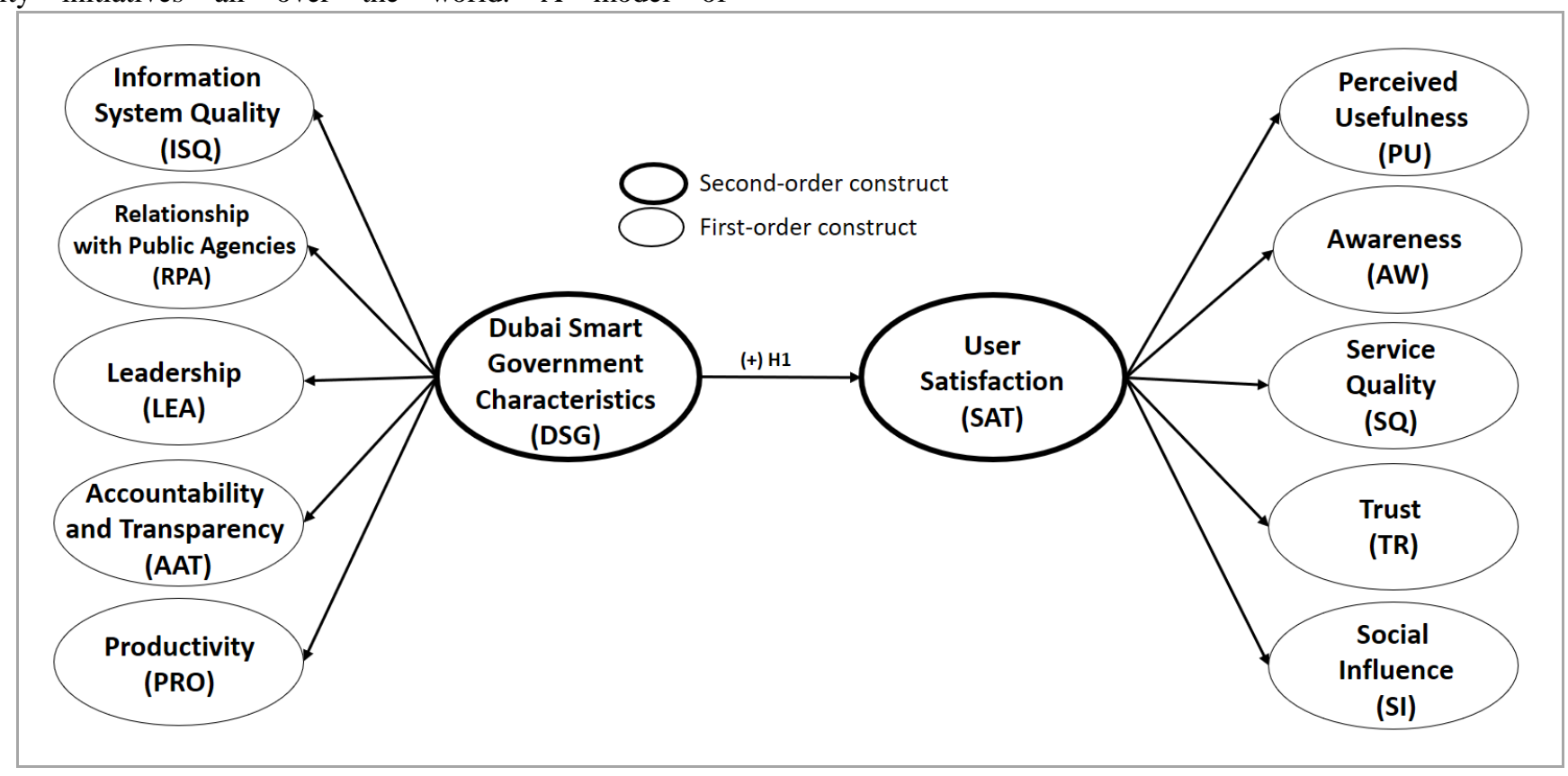

Fig.1. The proposed conceptual framework

\section{B. Development of Instrument and Data collection}

Online survey was found as the most suitable tool as smart government are directly operated through ICT and artificial platforms where the internet tool is necessary for both service provider and users. Variables were measured using a Likert Scale which recommended in the previous studies [31, 32]. Random sampling method was adopted to select the beneficiaries of Dubai smart government services. The sample size was determined as 250 users of Dubai smart government services, who are users who got the services from five major strategic or government partners of smart government establishment: Dubai Police, RTA, DEWA,
DHA, and Dubai Municipality. Accordingly, with the permission of Dubai smart office, 400 email addresses of beneficiaries of Dubai smart government initiatives were randomly collected in line with the above criteria. The questionnaire, which was designed through Google Forms, was sent to selected email until the sample size was met. However, only 231 respondents were achieved a response rate of $92.4 \%$, which is considered to be a healthier survey response rate.

\section{DATA ANALYSIS AND RESULTS}


PLS (Partial Least Squares) SEM-VB (Structural Equation Modelling-Variance Based) was employed to assess the research model by utilising the software SmartPLS 3.0 [33]. A two-phase analytical technique Hair, Hult, Ringle, \& Sarstedt, 2017) [34] consisting of (i) measurement model analysis (reliability and validity) and (ii) structural model analysis (examining the conceptualised relationships) was employed after performing the descriptive assessment. This two-phase analytical technique consisting of a structural and a measurement model assessment is better than a single phase assessment [35]. While the model of measurement explains each parameter's measurement, the structural model describes the correlation between the parameters in this model [34]. The main reasons for choosing SEM as a statistical method for this study is that SEM offers a simultaneous analysis which leads to more accurate estimates $[31,32]$.

\section{A.Descriptive analysis}

Table 1 presents the mean and standard deviation of each variable in the current study. The respondents were asked to indicate their opinion in relation to transformational leadership and human capital based on a 7-point scale ranging from 1 (strongly disagree) to 7 (strongly agree). Service quality scores the highest with mean 4.415 out of 7.0 , with a standard deviation of 0.808 .

\section{B. Measurement Model Assessment}

Construct reliability as well as validity (comprising discriminant and convergent validity) were used to examine the measurement model. The particular alpha coefficients of
Cronbach were tested to determine the reliability of every core parameter in the measurement model (construct reliability). The quantities of all the unique alpha coefficients of Cronbach in this research ranged from 0.818 to 0.901 , which went beyond the proposed value of 0.7 . Moreover, for inspecting construct reliability, all the CR (composite reality) values ranged from 0.892 to 0.938 , which went beyond 0.7 . Thus, as Table 1 shows, construct reliability has been fulfilled as Cronbach's CR and alpha were rather error-free for all the parameters.

Analysis of indicator reliability was conducted by utilising factor loadings. When the related indicators are very similar, this is reflected in the construct and signified by the construct's high loadings [34]. As per Joseph F. Hair Jr, William C. Black, Barry J. Babin, (2010) [35], the exceeding of values beyond 0.70 suggests substantial factor loadings. Table 1 displays that all articles in this research had factor loadings greater than the suggested value.

AVE (average variance extracted) was employed in this study to analyse convergent validity, which represents the degree to which a measure is correlated positively with the same construct's other measures. All the AVE values ranged from 0.734 and 0.835 , which went beyond the proposed value of 0.50 [35]. Thus, all constructs have complied with the convergent validity acceptably, as shown in Table 1.

Table 1: Mean, standard deviation, loading, cronbach's Alpha, CR and AVE

\begin{tabular}{|c|c|c|c|c|c|c|c|}
\hline Constructs & Item & $\begin{array}{l}\text { Loading } \\
(>0.7)\end{array}$ & M & SD & $\begin{array}{c}\alpha \\
(>0.7)\end{array}$ & $\begin{array}{c}\text { CR } \\
(>0.7)\end{array}$ & $\begin{array}{c}\text { AVE } \\
(>0.5)\end{array}$ \\
\hline $\begin{array}{c}\text { Information } \\
\text { System Quality } \\
\text { (ISQ) }\end{array}$ & $\begin{array}{l}\text { ISQ1 } \\
\text { ISQ2 } \\
\text { ISQ3 }\end{array}$ & $\begin{array}{l}0.851 \\
0.880 \\
0.853\end{array}$ & $\begin{array}{c}4.16 \\
0\end{array}$ & $\begin{array}{c}0.82 \\
7\end{array}$ & 0.827 & 0.896 & 0.742 \\
\hline $\begin{array}{l}\text { Relationship } \\
\text { with Public } \\
\text { Agencies } \\
\text { (RPA) } \\
\end{array}$ & $\begin{array}{l}\text { RPA1 } \\
\text { RPA2 } \\
\text { RPA3 }\end{array}$ & $\begin{array}{l}0.819 \\
0.895 \\
0.855\end{array}$ & $\begin{array}{c}4.23 \\
9\end{array}$ & $\begin{array}{c}0.84 \\
7\end{array}$ & 0.818 & 0.892 & 0.734 \\
\hline $\begin{array}{l}\text { Leadership } \\
\text { (LEA) }\end{array}$ & $\begin{array}{l}\text { LEA1 } \\
\text { LEA2 } \\
\text { LEA3 } \\
\end{array}$ & $\begin{array}{l}0.844 \\
0.877 \\
0.869 \\
\end{array}$ & $\begin{array}{c}4.21 \\
8\end{array}$ & $\begin{array}{c}0.83 \\
4\end{array}$ & 0.829 & 0.898 & 0.745 \\
\hline $\begin{array}{c}\text { Accountability } \\
\text { and } \\
\text { Transparency } \\
\text { (AAT) }\end{array}$ & $\begin{array}{l}\text { AAT1 } \\
\text { AAT2 } \\
\text { AAT3 }\end{array}$ & $\begin{array}{l}0.833 \\
0.897 \\
0.861\end{array}$ & $\begin{array}{c}4.17 \\
9\end{array}$ & $\begin{array}{c}0.84 \\
2\end{array}$ & 0.829 & 0.898 & 0.746 \\
\hline $\begin{array}{l}\text { Productivity } \\
\text { (PRO) }\end{array}$ & $\begin{array}{l}\text { PRO1 } \\
\text { PRO2 } \\
\text { PRO3 } \\
\end{array}$ & $\begin{array}{l}0.853 \\
0.865 \\
0.867\end{array}$ & $\begin{array}{c}4.16 \\
9\end{array}$ & $\begin{array}{c}0.80 \\
4\end{array}$ & 0.826 & 0.896 & 0.742 \\
\hline $\begin{array}{l}\text { Perceived } \\
\text { Usefulness } \\
\text { (PU) }\end{array}$ & $\begin{array}{l}\text { PU1 } \\
\text { PU2 } \\
\text { PU3 }\end{array}$ & $\begin{array}{l}0.878 \\
0.827 \\
0.869\end{array}$ & $\begin{array}{c}4.30 \\
9\end{array}$ & $\begin{array}{c}0.73 \\
1\end{array}$ & 0.822 & 0.893 & 0.737 \\
\hline $\begin{array}{c}\text { Awareness } \\
(\mathrm{AW})\end{array}$ & $\begin{array}{l}\text { AW1 } \\
\text { AW2 } \\
\text { AW3 }\end{array}$ & $\begin{array}{l}0.877 \\
0.896 \\
0.867\end{array}$ & $\begin{array}{c}4.22 \\
1\end{array}$ & $\begin{array}{c}0.81 \\
3\end{array}$ & 0.854 & 0.912 & 0.774 \\
\hline
\end{tabular}




\begin{tabular}{|c|c|c|c|c|c|c|c|}
\hline $\begin{array}{c}\text { Service } \\
\text { Quality } \\
\text { (SQ) }\end{array}$ & $\begin{array}{l}\text { SQ1 } \\
\text { SQ2 } \\
\text { SQ3 }\end{array}$ & $\begin{array}{l}0.920 \\
0.917 \\
0.904\end{array}$ & $\begin{array}{c}4.41 \\
5\end{array}$ & $\begin{array}{c}0.80 \\
8\end{array}$ & 0.901 & 0.938 & 0.835 \\
\hline $\begin{array}{l}\text { Trust } \\
\text { (TR) }\end{array}$ & $\begin{array}{l}\text { TR1 } \\
\text { TR2 } \\
\text { TR3 }\end{array}$ & $\begin{array}{l}0.909 \\
0.901 \\
0.895\end{array}$ & $\begin{array}{c}4.32 \\
0\end{array}$ & $\begin{array}{c}0.80 \\
6\end{array}$ & 0.885 & 0.929 & 0.813 \\
\hline $\begin{array}{c}\text { Social } \\
\text { Influence } \\
(\mathrm{SI})\end{array}$ & $\begin{array}{l}\text { SI1 } \\
\text { SI2 } \\
\text { SI3 }\end{array}$ & $\begin{array}{l}0.897 \\
0.915 \\
0.862\end{array}$ & $\begin{array}{c}4.40 \\
6\end{array}$ & $\begin{array}{c}0.81 \\
4\end{array}$ & 0.871 & 0.921 & 0.795 \\
\hline
\end{tabular}

Note: $\mathrm{M}=$ Mean; $\mathrm{SD}=$ Standard Deviation, $\alpha=$ Cronbach's alpha; $\mathrm{CR}=$ Composite Reliability, AVE = Average Variance Extracted.

Key: ISQ: information system quality; RPA: relationship with public agencies; LED: leadership; AAT: accountability and transparency; PRO: productivity; PU: perceived usefulness; AW: awareness; SQ: service quality; TR: trust; SI: social influence.

The degree to which the articles distinguish among concepts or measure different constructs is demonstrated by discriminant validity. Fornell-Larcker was employed to analyse the measurement model's discriminant validity. Table 2 shows the outcomes for discriminant validity by employing the Fornell-Larcker condition. It was discovered that the AVEs' square root on the diagonals (displayed in bold) is bigger than the correlations among constructs (corresponding row as well as column values), suggesting a strong association between the concepts and their respective markers in comparison to the other concepts in the model [36, 37]. According to Hair et al., (2017) [34], this indicates good discriminant validity. Furthermore, the exogenous constructs have a correlation of less than 0.85 [38]. Therefore, all constructs had their discriminant validity fulfilled satisfactorily.

Table 2: Results of discriminant validity by Fornell-Larcker criterion

\begin{tabular}{|c|c|c|c|c|c|c|c|c|c|c|}
\hline & $A A T$ & $A W$ & $I S Q$ & $L E A$ & $P R O$ & $P U$ & $R P A$ & $S I$ & $S Q$ & $T R$ \\
\hline AAT & 0.864 & & & & & & & & & \\
\hline AW & 0.525 & 0.880 & & & & & & & & \\
\hline ISQ & 0.758 & 0.442 & 0.862 & & & & & & & \\
\hline LEA & 0.787 & 0.487 & 0.750 & 0.863 & & & & & & \\
\hline PRO & 0.756 & 0.514 & 0.656 & 0.696 & 0.862 & & & & & \\
\hline PU & 0.556 & 0.728 & 0.502 & 0.559 & 0.539 & 0.858 & & & & \\
\hline RPA & 0.783 & 0.474 & 0.774 & 0.749 & 0.720 & 0.570 & 0.857 & & & \\
\hline SI & 0.514 & 0.730 & 0.438 & 0.488 & 0.491 & 0.738 & 0.489 & 0.892 & & \\
\hline SQ & 0.540 & 0.791 & 0.486 & 0.504 & 0.491 & 0.785 & 0.488 & 0.791 & 0.914 & \\
\hline TR & 0.520 & 0.765 & 0.441 & 0.453 & 0.485 & 0.738 & 0.477 & 0.703 & 0.802 & 0.902 \\
\hline
\end{tabular}

Note: Diagonals represent the square root of the average variance extracted while the other entries represent the correlations.

Key: ISQ: information system quality; RPA: relationship with public agencies; LED: leadership; AAT: accountability and transparency; PRO: productivity; PU: perceived usefulness; AW: awareness; SQ: service quality; TR: trust; SI: social influence.

\section{Structural Model Assessment}

The structural model can be tested by computing beta procedure with a resample of 5,000 [34].

$(\beta), \mathrm{R}^{2}$, and the corresponding t-values via a bootstrapping 


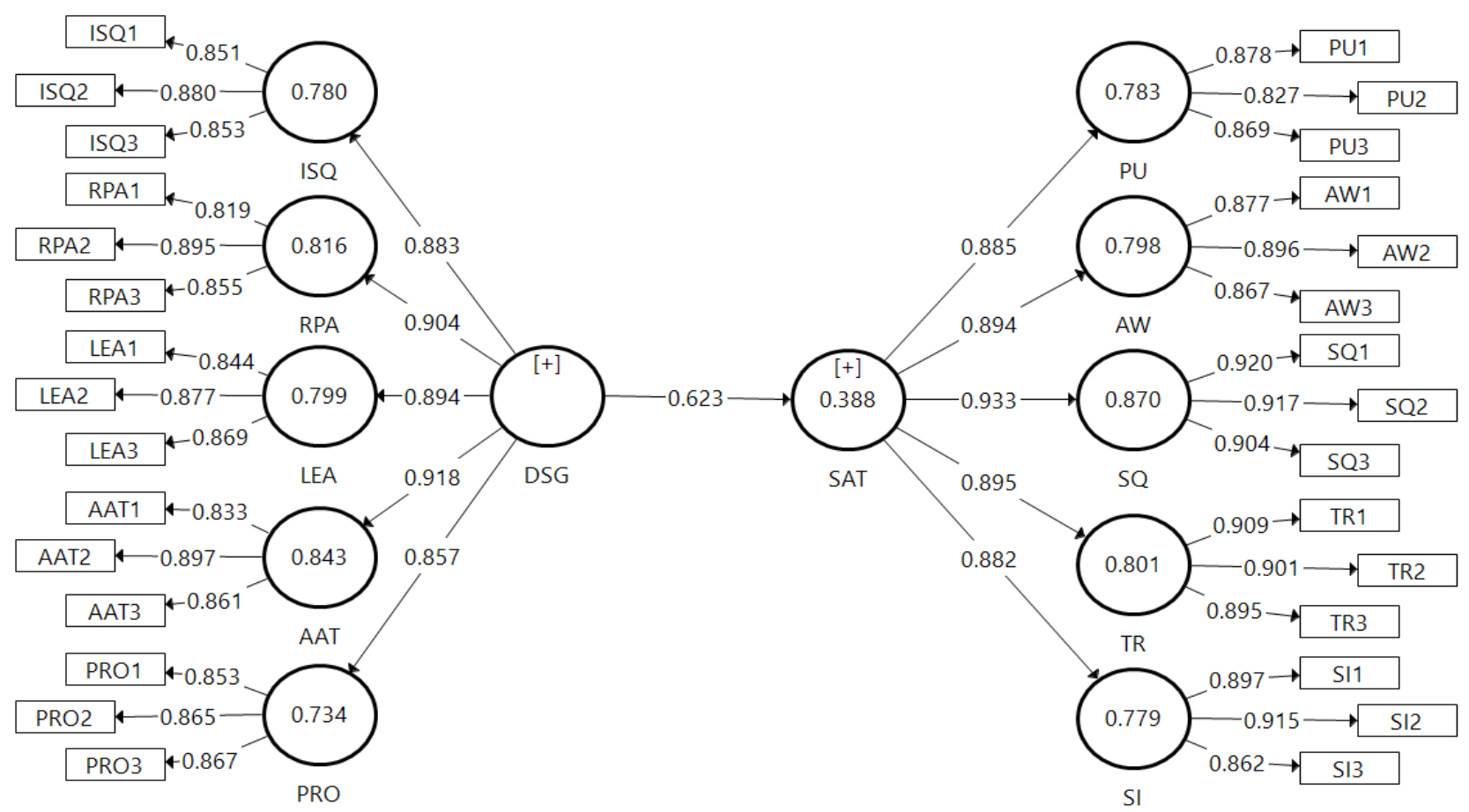

Key DSG: Dubai smart government characteristics; ISQ: information system quality; RPA: relationship with public agencies; LED: leadership; AAT: accountability and transparency; PRO: productivity; SAT: user satisfaction; PU: perceived usefulness; AW: awareness; SQ: service quality; TR: trust; SI: social influence

Fig 2: PLS algorithm results

Figure 2 and Table 3 depict the structural model assessment, showing the results of the hypothesis tests. Dubai smart government characteristics positively influence user satisfaction. Hence, $\mathrm{H} 1$ is accepted with $(\beta=0.623, \mathrm{t}=6.942, \mathrm{p}<0.001)$. Thirty-nine percent of the variance in user satisfaction is explained by Dubai smart government characteristics. The values of $\mathrm{R}^{2}$ have an acceptable level of explanatory power, indicating a substantial model [37].

Table 3: Structural path analysis result

\begin{tabular}{cccccccc}
\hline \hline \multirow{2}{*}{ Hypothesis } & Relationship & $\begin{array}{c}\text { Std } \\
\text { Beta }\end{array}$ & $\begin{array}{c}\text { Std } \\
\text { Error }\end{array}$ & t-value & p-value & Decision & $\mathrm{R}^{2}$ \\
\hline \multirow{2}{*}{$\mathrm{H} 1$} & DSG $\rightarrow$ & & & & & Supported \\
& SAT & 0.623 & 0.090 & 6.942 & 0.000 & 9.3 \\
\hline \hline
\end{tabular}

Key: DSG: Dubai smart government characteristics; SAT: user satisfaction.

\section{DISCUSSION}

The main objective of this study is to address the impact level of Dubai smart government characteristics on the user satisfaction. The suggested hypothesis was supported with $(\beta=0.623, \mathrm{t}=6.942, \mathrm{p}<0.001)$. This indicates that there is a positive direct impact of Dubai smart government characteristics on the user satisfaction. This is result is explained by the fact that the more quality of Dubai smart government programs system is high and reliable, Dubai government effectively coordinates and collaborates its smart government establishment with its all public agencies, The leadership Smart Dubai Government Establishment is visionary and effective, Smart Dubai Government Establishment facilitates access to information, economic activity and conduct of business, Smart Dubai Government Establishment improves the productivity in the state; the more the users perceive that smart Dubai government establishment is useful or beneficial to them, The users are aware of smart government services being provided in Dubai, The users find that Dubai smart government systems demonstrate the quality features, The users of Smart Dubai Government services trust in Dubai government, and The users are influenced to use smart government services by their families, friends, and communities with which they live. Overall, H1 was supported and indicates that there is a positive direct impact of Dubai smart government characteristics on the user satisfaction of smart Dubai government services.

\section{IMPLICATIONS, LIMITATIONS AND FUTURE DIRECTIONS}

At the beginning, the study is significant to Dubai government as its smart government initiatives primarily aim to enhance happiness of people living in Dubai. Enhancing happiness of residents denotes the satisfaction of residents' as to overall initiatives of Dubai Smart Government establishment, and thus, the measurement and evaluation of the level of residents' satisfaction, which arises as a consequence of Dubai Smart Government establishment is vital. 
Accordingly, the findings of this study in relation to Dubai Smart Government establishment facilitate the government to make decisions in relation to their initiatives. For example, the findings of this paper will enable Dubai government to identify whether Dubai Smart Government initiatives have significantly been able to influence the residents' satisfaction level by which their ultimate outcome of increasing happiness of people can be assessed.

On the other hand, the typical assessment by using feedback of the systems will not always reflect the reality with respect to the level of residents' satisfaction as it does not account for residents who have not used or are unable to use such smart government applications. Thus, such assessment may extravagate the benefits of such initiatives. However, the current study targeted to survey randomly selected residents of Dubai to measure and approximate the level of residents' satisfaction towards Dubai Smart Government initiatives, and thus relatively a larger audience, which can include many types of users of smart government applications could be used for the research.

\section{CONCLUSION}

The main objective of this study was to define antecedents that affect the user satisfaction of Dubai smart government services. The findings have shed encouraging lights on some characteristics such as (Information System Quality, Relationship with Public Agencies, Leadership, Accountability and Transparency, and Productivity) that influence the user satisfaction. The results from the statistical analysis showed that there is a positive direct impact of Dubai smart government characteristics on the user satisfaction. These characteristics will improve the Perceived Usefulness, Awareness, Service Quality, Trust, and Social Influence, as the user satisfaction indicators. Nevertheless, of the limitations of this study, results have managed to shed some lights on the impact of Dubai smart government characteristics on the user satisfaction, which is encouraging results. In summary, Dubai government needs to improve the characteristics of Dubai smart government to reach the ultimate user satisfaction.

\section{APPENDIX}

Appendix A

Instrument for varibles

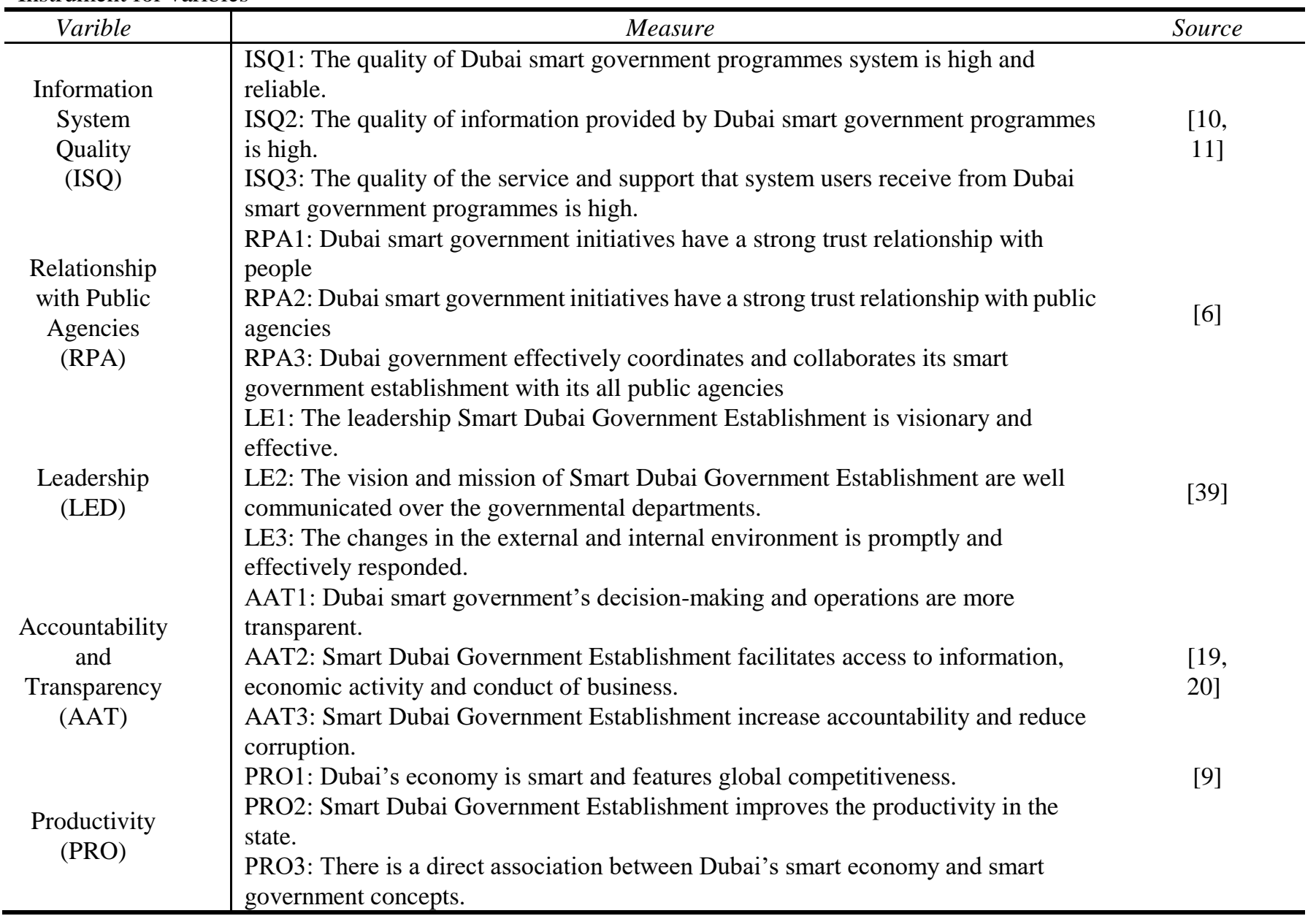


Perceived

PU1: The users perceive that smart Dubai government establishment is useful or

Usefulness

$(\mathrm{PU})$

beneficial to them.

PU2: The users perceive that smart Dubai government establishment is easy to use.

PU3: The perceived usefulness \& ease of use were actually featured when receiving

Dubai smart government services.

Awareness

AW1: The users are aware of smart government services being provided in Dubai.

AW2: The users are well aware of how to use smart government systems.

AW3: Awareness increases the level of intention to use smart government services.

Service

Quality

SQ1: The users find that Dubai smart government systems demonstrate the quality features.

SQ2: The users find that information and data provided by Dubai smart government systems and services demonstrates acceptable and reliable.

SQ3: The users receive quality services from Dubai smart government information systems.

TR1: The users of Smart Dubai Government services trust in the internet.

TR2: The users of Smart Dubai Government services trust in Dubai government.

Trust

TR3: The critical issues relating to public safety was not encountered by the users of the services.

(TR)

SI1: The users believe and consider the perceptions of their families, friends, and colleagues regarding smart government services in Dubai.

Social

Influence

SI2: The users are influenced to use smart government services by their families,

friends, and communities with which they live.

SI3: The users are likely to use smart government system in the future if their friends and colleagues use it.

\section{REFERENCES}

1. I. M. Hassan, A. A. Mahdi \& N. J. Al-Khafaji, (2012). THEORETICAL STUDY TO HIGHLIGHT THE SMART GOVERNMENT COMPONENTS IN 21st CENTURY. International Journal of Computer Science and Mobile Computing, 3(12), pp. 333-347.

2. A. H. Aldholay, Z. Abdullah, T. Ramayah, O. Isaac \& A. M. Mutahar (2018). Online learning usage and performance among students within public universities in Yemen. International Journal of Services and Standards, 12(2), pp. 163-178.

3. A. H. Aldholay, O. Isaac, Z. Abdullah \& T. Ramayah (2018). The role of transformational leadership as a mediating variable in DeLone and McLean information system success model: The context of online learning usage in Yemen. Telematics and Informatics, 35(5), pp. $1421-1437$

4. Puron-Cid, (2015). Smart City: How to Create Public and Economic Value with High Technology in Urban Space. International Journal of E-Planning Research, 4, pp. 74-76.

5. R. Giffinger, C. Fertner, H. Kramar, R. Kalasek, N. Milanović \& E. Meijers, (2007). Smart cities - Ranking of European medium-sized cities. Vienna University of Technology.

6. S. Al-Shafi \& V. Weerakkody (2010). Factors affecting e-government adoption in the state of Qatar. In European and Mediterranean Conference on Information Systems 2010 (EMCIS2010) pp. 1-23. Abu Dhabi, UAE.

7. S. Alawadhi \& H. Scholl (2016). Smart Governance: A Cross-Case Analysis of Smart City Initiatives. In 49th Hawaii International Conference on System Sciences (HICSS) pp. 2953-2963. Koloa, HI, USA.

8. O. Ashamsi \& A. Ameen, (2018). The Impact of Smart Government on The Residents' Satisfaction in Dubai: The Performance of Dubai Governmental Departments as Mediator Variables. In 2nd International Conference on Management and Human Science (ICMHS 2018), pp. 27-28 November 2018, Kuala Lumpur, Malaysia (p. 2018).

9. H. Chourabi, T. Nam, S. Walker, J. R. Gil-Garcia, S. Mellouli, K. Nahon, ... H. Scholl, (2012). Understanding Smart Cities: An Integrative Framework. 45th Hawaii International Conference on System Sciences.

10. W. DeLone \& E. R. McLean (2013). Information Systems Success: The Quest for the Independent Variables AU - Petter, Stacie. Journal of Management Information Systems, 29(4), pp. 7-62.

11. H. Elkadi, (2013). Success and failure factors for e-government projects: A case from Egypt. Egyptian Informatics Journal, 14(2), pp. 165-173.

12. A.-O. Fahad \& A. Ameen (2017). Toward Proposing SMART-Government Maturity Model: Best Practices, International Standards, and Six-Sigma Approach. In 1st International Conference

on Management and Human Science (ICMHS 2017) (p. 2017). Kuala Lumpur, Malaysia.

13. D. Al-Ali \& A. Ameen (2018). The Influence of System Quality and Information Quality on User Satisfaction: The Case of Smart Government in UAE. In 2nd International Conference on Management and Human Science (ICMHS 2018), 27-28 November 2018, Kuala Lumpur, Malaysia (Vol. 7, pp. 58-74).

14. K. Al-Ali, A. Ameen \& I. Alrajawy (2018). The Role of SMART Government on Enhancing Pubic Service Quality: Performance Quality Is a Mediator Factor. In International Conference on Recent Trends in Business and Entrepreneurial Ventures (ICRTBEV2018) (p. 23).

15. S. Albreki \& A. Ameen (2018). Identify the Underlying Factors that Effecting the Relationship between Knowledge Management and Smart Government in UAE. In 2nd International Conference on Management and Human Science (ICMHS 2018), pp. 27-28.

16. N. Odendaal, (2003). Information and communication technology and local governance: Understanding the difference between cities in developed and emerging economies. Computers, Environment and Urban Systems Vol. 27.

17. Smart Dubai Government Establishment. (2017). About Dubai Smart Government.

18. C. A. Dykstra (1939). The Quest for Responsibility. American Political Science Review, 33(1), pp. 1-25.

19. S. Alawadhi \& H. Scholl (2013). Aspirations and Realizations: The Smart City of Seattle. In Proceedings of the Annual Hawaii International Conference on System Sciences pp. 1695-1703.

20. M. do R. M. Bernardo (2017). Smart City Governance: From E-Government to Smart Governance. In Handbook of Research on Entrepreneurial Development and Innovation Within Smart Cities (pp. 290-326)

21. Smartcity. (2018). Driving Forces That Stimulate The Growth Of Smart Cities.

22. A. T. Chatfield \& J. M. Alanazi (2013). Service quality, citizen satisfaction, and loyalty with self-service delivery options to transforming e-government services. Proceedings of the 24th Australasian Conference on Information Systems.

23. F. D. Davis, (1989). Perceived Usefulness, Perceived Ease Of Use, And User Acceptance. MIS Quarterly, 13(3), pp. 319-339.

24. N. Almuraqab \& S. M. Jasimuddin, (2017). Factors that Influence End-Users' Adoption of Smart Government Services in the UAE: A

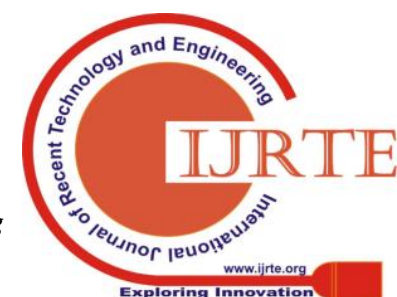


Conceptual Framework. Electronic Journal of Information Systems Evaluation Vol. 20.

25. L. Carter \& F. Bélanger (2005). The utilization of e-government services: citizen trust, innovation and acceptance factors*. Information Systems Journal, 15(1), pp. 5-25.

26. A. Thunibat, N. Azan Mat Zain \& N. Ashaari, (2011). Modelling the factors that influence mobile government services acceptance. African journal of business management Vol. 5 .

27. M. Dahi \& Z. Ezziane (2015). Measuring e-government adoption in Abu Dhabi with technology acceptance model (TAM). International Journal of Electronic Governance Vol. 7.

28. S. Mofleh \& M. Wanous (2008). Understanding Factors Influencing Citizens Adoption of e-Government Services in the Developing World: Jordan as a Case Study. J Comput Sci (Vol. 7).

29. H. Abdelghaffar \& Y. Magdy (2012). The Adoption of Mobile Government Services in Developing Countries: The Case of Egypt. International Journal of Information Vol. 2.

30. A. Aldholay, O. Isaac, Z. Abdullah, R. Abdulsalam \& A. H. Al-Shibami (2018). An extension of Delone and McLean IS success model with self-efficacy. International Journal of Information and Learning Technology, IJILT-11-2017-0116.

31. O. Isaac, Z. Abdullah, T. Ramayah \& A. M. Mutahar, (2017a). Internet Usage and Net Benefit among Employees Within Government Institutions in Yemen: An Extension of Delone and Mclean Information Systems Success Model (DMISM) with Task-Technology Fit. International Journal of Soft Computing, 12(3), pp. 178-198.

32. O. Isaac, Z. Abdullah, T. Ramayah \& M. Mutahar Ahmed (2017). Examining the Relationship Between Overall Quality, User Satisfaction and Internet Usage: An Integrated Individual, Technological, Organizational and Social Perspective. Asian Journal of Information Technology, 16(1), pp. 100-124.

33. C. M. Ringle, S. Wende \& J.-M. Becker (2015). SmartPLS 3. Bonningstedt: SmartPLS.

34. J. F. Hair, G. T. M. Hult, C. Ringle \& M. Sarstedt (2017). A Primer on Partial Least Squares Structural Equation Modeling (PLS-SEM) (2nd ed.). London: Thousand Oaks: SAGE.

35. Joseph F. Hair Jr, William C. Black, Barry J. Babin, R. E. A. (2010). Multivariate Data Analysis (7th ed.). Prentice Hall.

36. C. Fornell \& D. F. Larcker (1981). Evaluating structural equation models with unobservable variables and measurement error. Journal of Marketing Research, 18(1), pp. 39-50.

37. W. W.Chin (1998a). Issues and opinion on structural equation modeling. MIS Quarterly, 22(1), pp. 7-16.

38. Z. Awang (2014). Structural Equation Modeling Using AMOS. Shah Alam.Malaysia: University Teknologi MARA Publication Center.

39. N. Lopes (2017). Smart governance: A key factor for smart cities implementation. In IEEE International Conference on Smart Grid and Smart Cities (ICSGSC) (pp. 277-282) 